\title{
Effect of White Mud Addition on Desulfurization Rate of Molten Steel
}

\author{
TAE SU JEONG, MIN KYO OH, YONGSUG CHUNG, and JOO HYUN PARK
}

Fluorspar $\left(\mathrm{CaF}_{2}\right)$ is commonly used to control the fluidity of slag in ladle-refining of steel. However, because it is desirable to reduce $\mathrm{CaF}_{2}$ consumption because of its environmental impacts, the industrial waste material such as white mud (WM) was investigated as a potential substitute for fluorspar. Steel sample (Fe-0.3C-0.9Mn-0.3Si-0.03Al-0.05S, mass pct) was melted in a high-frequency induction furnace, followed by additions of ladle slag $\left(\mathrm{CaO}-\mathrm{Al}_{2} \mathrm{O}_{3}-\mathrm{SiO}_{2}-5 \mathrm{MgO}-x \mathrm{CaF}_{2}, \mathrm{CaO} / \mathrm{Al}_{2} \mathrm{O}_{3}=3, x=0\right.$ to 10 mass pet) and fluxing agent $(\mathrm{WM})$ at $1823 \mathrm{~K}\left(1550{ }^{\circ} \mathrm{C}\right)$. The desulfurization experiments were carried out by reducing $\mathrm{CaF}_{2}$ content in the ladle slag and increasing the addition of WM. Ladle slag with added WM showed an overall mass transfer coefficient of sulfur $\left(k_{\mathrm{O}}\right)$ equivalent to or higher than that of conventional 10 mass pct $\mathrm{CaF}_{2}$-containing ladle slag. In a slag melting experiment based on DIN 51730 standard, the melting rate of mixed slag increased with the amount of WM added, which is considered to have a positive effect on the initial desulfurization rate. In addition, adding WM provided sulfide capacity of the slag equivalent to that of $\mathrm{CaF}_{2}$-containing slag. Consequently, the use of WM yielded slag having $k_{\mathrm{O}}$ equivalent to or higher than that of conventional ladle slag with 10 pct $\mathrm{CaF}_{2}$, and thus, WM shows promise as a partial replacement for fluorspar.

https://doi.org/10.1007/s11663-021-02343-y

(C) The Author(s) 2021

\section{INTRODUCTION}

IT is generally accepted that the lower the viscosity of slag, the more positive its desulfurization effect in ladle-refining process. ${ }^{[1]}$ Putan et al. ${ }^{[2]}$ reported that steel-slag interfacial reaction rate decreased as the viscosity of the slag increased. Fluorspar $\left(\mathrm{CaF}_{2}\right)$ is one of the materials commonly used as a fluxing agent in ladle-refining stage to ensure a high liquid slag fraction of low viscosity. Thus, many researchers have studied the effects of $\mathrm{CaF}_{2}$ upon the viscosity of slag, ${ }^{[3-10]}$ and have explained that the fluoride ion depolymerizes silicate networks, thereby increasing the fluidity of the slag. ${ }^{[7-9]}$ Park et al. ${ }^{[9]}$ measured the viscosity of $\mathrm{CaO}-\mathrm{SiO}_{2}(-\mathrm{MgO})-\mathrm{CaF}_{2}$ slag and explained that the effect of $\mathrm{CaF}_{2}$ upon slag viscosity can be understood

TAE SU JEONG and MIN KYO OH are with the Department of Materials Science and Chemical Engineering, Hanyang University, Ansan 15588, Korea. YONGSUG CHUNG is with the Department of Advanced Materials Engineering, Korea Polytechnic University, Siheung 15073, Korea. JOO HYUN PARK is with the Department of Materials Science and Chemical Engineering, Hanyang University, Ansan 15588, Korea and also with the Department of Materials Science and Engineering, KTH Royal Institute of Technology, Stockholm 100 44, Sweden. Contact e-mail: basicity@ hanyang.ac.kr Manuscript submitted April 27, 2021; accepted September 29, 2021. Article published online October 26, 2021. to arise from a decrease in polymerization degree by $\mathrm{F}^{-}$ ions and reported that the effect of $\mathrm{CaF}_{2}$ upon viscosity was significant in the highly basic multiphase (i.e., solid + liquid coexisting) system. Kim and Park ${ }^{[10]}$ observed that the viscosity of low-silica $\left(\mathrm{SiO}_{2} \leq 10\right.$ mass pet) calcium aluminosilicate melts having fixed contents of $\mathrm{MgO}$ (5 mass pct), representing the Al-killed slag, decreased with increasing basicity $\left(\mathrm{CaO} / \mathrm{SiO}_{2}\right.$ or $\mathrm{CaO} /$ $\mathrm{Al}_{2} \mathrm{O}_{3}$ ) and that the addition of a small quantity of $\mathrm{CaF}_{2}$ (5 mass pct) liberated the $\left[\mathrm{SiO}_{4}\right]^{4-}$ silicate unit from the aluminate network and thereby decreased the slag viscosity. However, the additional effect was insignificant when more than 10 mass pet $\mathrm{CaF}_{2}$ was added.

Alternatively, the researchers have studied the melting properties of slag with added $\mathrm{CaF}_{2} \cdot{ }^{[3,11,12]}$ In general, as $\mathrm{CaF}_{2}$ is added, the melting point of the slag decreases. ${ }^{[3]}$ Suk and Park ${ }^{[11]}$ performed a slag melting experiment using a cylindrical slag samples $\left(\mathrm{CaO}-\mathrm{SiO}_{2}-\mathrm{MgO}-\mathrm{CaF}_{2}\right.$, $3 \mathrm{~mm} \times 3 \mathrm{~mm}$ ) based on the DIN 51730 standard method and observed that the sample height decreased more rapidly as the $\mathrm{CaF}_{2}$ content was increased. Wang et al. ${ }^{[12]}$ performed a slag melting experiment using a cylindrical slag sample $\left(\mathrm{CaO}-\mathrm{SiO}_{2}-\mathrm{Fe}_{2} \mathrm{O}_{3}-\mathrm{CaF}_{2}, 3 \mathrm{~mm} \times\right.$ $3 \mathrm{~mm}$ ), measuring the hemisphere temperature $\left(T_{\mathrm{h}}\right)$, at which the height of the slag sample was reduced to half its original height, and the flow temperature $\left(T_{\mathrm{f}}\right)$, at 
which the height of sample was reduced to one-third its original height. They observed that both $T_{\mathrm{h}}$ and $T_{\mathrm{f}}$ decreased with additional $\mathrm{CaF}_{2}$.

However, the addition of $\mathrm{CaF}_{2}$ can further accelerate refractory degradation. ${ }^{[11-14]}$ Han et al. ${ }^{[13]}$ investigated refractory degradation and slag penetration depending on $\mathrm{CaF}_{2}$ content by using $\mathrm{CaO}-\mathrm{Al}_{2} \mathrm{O}_{3}-\mathrm{SiO}_{2}-\mathrm{MgO}-x-$ $\mathrm{CaF}_{2}\left(x=0\right.$ to 15 mass pct) slag at $1823 \mathrm{~K}\left(1550^{\circ} \mathrm{C}\right)$. As the content of $\mathrm{CaF}_{2}$ increased, detachment of $\mathrm{MgO}$ grains was observed, and the slag penetration into the refractory increased. It was concluded that the addition of $\mathrm{CaF}_{2}$ reduced the viscosity of the slag, which accelerated the erosion of the refractory material. Also, penetrated slag containing $\mathrm{CaF}_{2}$ reacts with the refractory binder and detaches $\mathrm{MgO}$ grains, damaging the refractory material. Park et al. ${ }^{[1,14]}$ found that when $\mathrm{CaF}_{2}$ was added to calcium silicate slag, the slag fluidity increased, and that the $\mathrm{CaF}_{2}$ accelerated the corrosion of zirconia and magnesia refractories by promoting dissolution of the intermediate $\mathrm{CaZrO}_{3}$ and of $\mathrm{MgO}$.

Additionally, the fluorine in $\mathrm{CaF}_{2}$ is released from industrial slag as fluoride silicate gas, which is well known to be harmful. ${ }^{[1,14-18]}$ When the fluorine-containing slag is dumped, high-fluorine soil can be formed, and the fluorine is dissolved in rain or groundwater, which pollutes the environment. ${ }^{[19,20]}$ So, the amount of $\mathrm{CaF}_{2}$ used industrially should be decreased for environmental reasons. Moreover, because the price of fluorspar is also increasing, ${ }^{[21]}$ it is also required to reduce the amount of fluorspar used for economic reasons.

Previous researchers have investigated several substances to replace the fluorspar used in the desulfurization of hot metal. ${ }^{[8,16,22-24]}$ They concluded that labradorite, potassium feldspar, nepheline syenite, and ilmenite minerals could be used as alternative fluxing agents. Choi et al. ${ }^{[24]}$ conducted a desulfurization experiment of hot metal at $1623 \mathrm{~K}\left(1350{ }^{\circ} \mathrm{C}\right)$ using the $\mathrm{CaO}-\mathrm{SiO}_{2}-\mathrm{Al}_{2} \mathrm{O}_{3}-\mathrm{Na}_{2} \mathrm{O}$ slag without $\mathrm{CaF}_{2}$, and Tong et al. ${ }^{[25]}$ conducted a desulfurization experiment of hot metal at $1773 \mathrm{~K}\left(1500{ }^{\circ} \mathrm{C}\right)$ by using the $\mathrm{CaO}-\mathrm{SiO}_{2}-\mathrm{A}$ $1_{2} \mathrm{O}_{3}-\mathrm{Na}_{2} \mathrm{O}-\mathrm{MgO}-\mathrm{TiO}_{2}$ slag. Both groups observed appropriate desulfurization efficiency. Fundamental studies on fluorspar substitutes have been conducted by previous researchers, but most have focused on fluidity rather than the refining efficiency of slag and have been carried out at relatively low temperatures to simulate hot metal pretreatment conditions.

In our previous study, ${ }^{[26]}$ desulfurization experiments of molten steel were conducted at $1823 \mathrm{~K}\left(1550{ }^{\circ} \mathrm{C}\right)$ while reducing the $\mathrm{CaF}_{2}$ content and adding industrial wastes (FeMn slag and red mud). FeMn slag (FMS) and red mud (RM) contain approx. 40 mass pet $\mathrm{MnO}$ or $\mathrm{Fe}_{2} \mathrm{O}_{3}$, respectively. However, the addition of small amounts of FMS or RM did not produce large changes to the slag composition and provided desulfurization efficiency equivalent to that of conventional 10 pct $\mathrm{CaF}_{2}$ ladle slag. McLean et al. ${ }^{[27]}$ conducted a desulfurization experiment on hot metal at $1673 \mathrm{~K}\left(1400{ }^{\circ} \mathrm{C}\right)$ using white mud (WM) and observed high desulfurization efficiency. WM is the industrial waste of alumina production by means of the lime sintering process, consisting of $\mathrm{CaO}, \mathrm{Al}_{2} \mathrm{O}_{3}, \mathrm{SiO}_{2}, \mathrm{MgO}$, and $\mathrm{Na}_{2} \mathrm{O}$. WM is a calcium aluminate-based flux as similar as ladle slag and does not contain $\mathrm{Fe}_{2} \mathrm{O}_{3}$, a reducible component. Hence, it is expected that the addition of WM will promote the desulfurization efficiency of molten steel.

Therefore, in the present study, slag melting and desulfurization experiments were conducted to reduce the consumption of fluorspar used relative to conventional ladle-refining slags. WM was added as a fluxing agent to determine whether this material can be used as a fluorspar substitute for desulfurization reactions.

\section{EXPERIMENTAL PROCEDURE}

The experimental apparatus used to observe melting behavior of mixed slags is shown in Figure 1. The sample was heated by a horizontal tube furnace and images of the sample during melting were obtained using a charge-coupled device (CCD) camera. Based on the standard method (DIN 51730 and KS E ISO 540), temperatures were measured when the shape of the sample began to change ( $=$ deformation temperature;

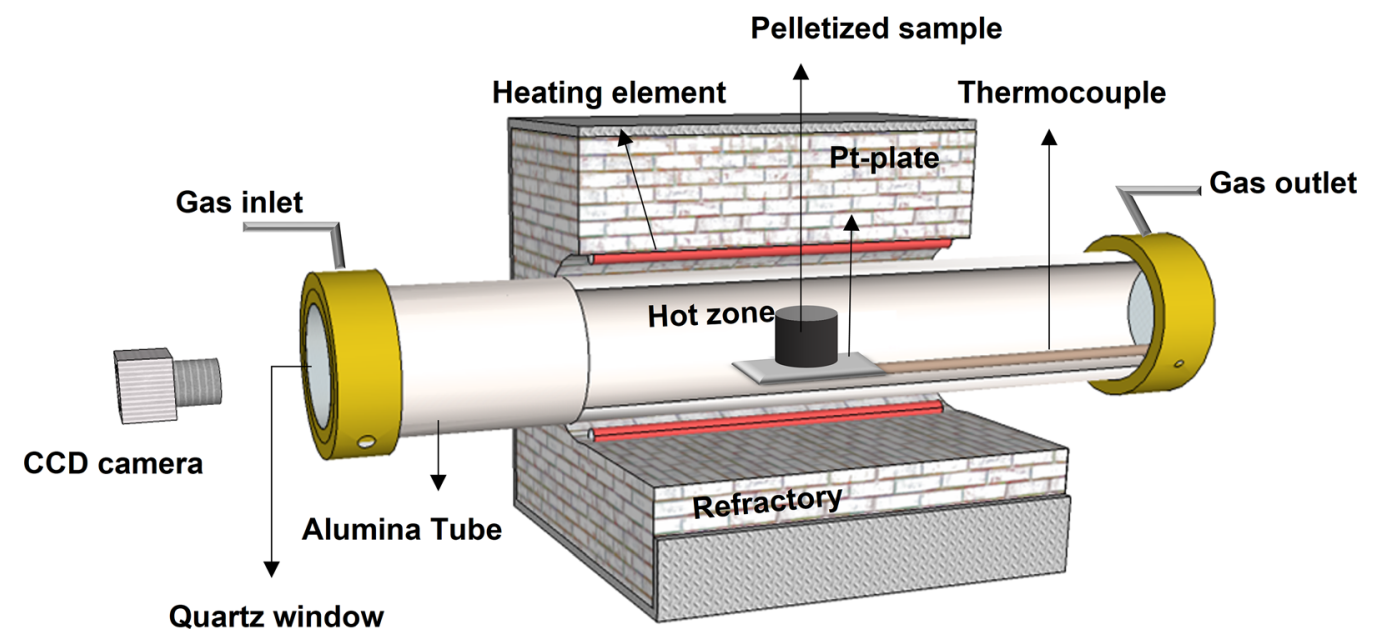

Fig. 1-Schematic diagram of the horizontal furnace for slag melting experiments. 
Table I. Compositions of Slag and White Mud Used in the Current Study (Mass Pet)

\begin{tabular}{llcccccc}
\hline & & $\mathrm{CaO}$ & $\mathrm{SiO}_{2}$ & $\mathrm{Al}_{2} \mathrm{O}_{3}$ & $\mathrm{MgO}$ & $\mathrm{CaF}_{2}$ & $\mathrm{Na}_{2} \mathrm{O}$ \\
\hline Ladle Slag (LS) & $10 \mathrm{CaF}_{2} \mathrm{LS}$ & 56.2 & 10.0 & 18.8 & 5.0 & 10.0 & - \\
& $7 \mathrm{CaF}_{2}$ LS & 58.5 & 10.0 & 19.5 & 5.0 & 7.0 & - \\
& $3 \mathrm{CaF}_{2}$ LS & 61.5 & 10.0 & 20.5 & 5.0 & - \\
White Mud (WM) & $0 \mathrm{CaF}_{2}$ LS & 63.8 & 10.0 & 21.2 & 5.0 & - & - \\
\hline
\end{tabular}

Table II. Initial Compositions of Mixed Slags Used in the Current Study (Mass Pet)

\begin{tabular}{|c|c|c|c|c|c|c|c|}
\hline & & $\mathrm{CaO}$ & $\mathrm{SiO}_{2}$ & $\mathrm{Al}_{2} \mathrm{O}_{3}$ & $\mathrm{MgO}$ & $\mathrm{CaF}_{2}$ & $\mathrm{Na}_{2} \mathrm{O}$ \\
\hline \multirow[t]{5}{*}{ WM-Fluxed Slag } & $3 \mathrm{CaF}_{2} \mathrm{LS}+5 \mathrm{WM}$ & 60.8 & 9.6 & 21.5 & 4.8 & 2.8 & 0.5 \\
\hline & $3 \mathrm{CaF}_{2} \mathrm{LS}+10 \mathrm{WM}$ & 60.0 & 9.3 & 22.5 & 4.6 & 2.7 & 0.9 \\
\hline & $7 \mathrm{CaF}_{2} \mathrm{LS}+10 \mathrm{WM}$ & 57.3 & 9.3 & 21.6 & 4.6 & 6.3 & 0.9 \\
\hline & $7 \mathrm{CaF}_{2} \mathrm{LS}+20 \mathrm{WM}$ & 56.2 & 8.5 & 23.7 & 4.2 & 5.6 & 1.8 \\
\hline & $7 \mathrm{CaF}_{2} \mathrm{LS}+30 \mathrm{WM}$ & 55.0 & 7.8 & 25.8 & 3.8 & 4.9 & 2.7 \\
\hline
\end{tabular}

$\left.T_{d}\right)$ and when the sample decreased to half ( $=$ hemisphere temperature; $T_{h}$ ) and one-third (= flow temperature; $T_{f}$ ) of its original height. A cylindrical pressed pellet of $6 \mathrm{~mm}$ diameter $\times 6 \mathrm{~mm}$ height made of slag powder was put onto a platinum plate $(20 \mathrm{~mm} \times 20 \mathrm{~mm}$ $\times 2 \mathrm{~mm}$ thickness), installed in the furnace, and then heated to $1873 \mathrm{~K}\left(1600{ }^{\circ} \mathrm{C}\right)$ at a rate of $5 \mathrm{~K} / \mathrm{min}\left(5^{\circ} \mathrm{C} /\right.$ min) in a chemically purified argon atmosphere.

Desulfurization experiments of molten steel were conducted using a high-frequency induction furnace, which was employed in the authors' previous works. ${ }^{[13,26]}$ To remove impurities from the quartz reaction chamber, a rotary vane pump was used, and then the chamber was filled with a high-purity Ar-3 pct $\mathrm{H}_{2}$ gas mixture, using a mass flow controller. The steel (Fe-0.9Mn-0.3Si-0.3C-0.05S-0.03Al, mass pct, $600 \mathrm{~g}$ ) was located in a fused magnesia crucible (outer diameter: $60 \mathrm{~mm}$, inner diameter: $50 \mathrm{~mm}$, and height: 120 $\mathrm{mm}$ ) for induction heating with a graphite heater (outer diameter: $80 \mathrm{~mm}$, inner diameter: $65 \mathrm{~mm}$, and Height: $120 \mathrm{~mm}$ ), which was surrounded by an insulating material. Impurities in the gas mixture were removed by purification system through Drierite (W.A. Hammond Drierite Co. Ltd., Xenia, $\mathrm{OH}$ ), soda lime, silica gel (medium granular, 5 to $10 \mathrm{mesh}$ ), and $\mathrm{Mg}$ turnings at $723 \mathrm{~K}\left(450{ }^{\circ} \mathrm{C}\right)$.

The experimental temperature was $1823 \mathrm{~K}\left(1550{ }^{\circ} \mathrm{C}\right)$, which was kept within $\pm 2 \mathrm{~K}\left( \pm 2{ }^{\circ} \mathrm{C}\right)$ using a B-type (Pt-30Rh / Pt-6Rh, mass pct) thermocouple and a proportional integral differential controller. After the temperature stabilized, the mixed slag (pre-fused master slag $+\mathrm{WM} ; 60 \mathrm{~g}$ ) was added onto the surface of the molten steel through the quartz tube under an Ar-3 pct $\mathrm{H}_{2}$ gas atmosphere. The synthenic slag was prepared by melting reagent-grade $\mathrm{CaO}, \mathrm{Al}_{2} \mathrm{O}_{3}, \mathrm{SiO}_{2}, \mathrm{MgO}$, and $\mathrm{CaF}_{2}$ in a vertical resistance tube furnace in the purified $\mathrm{Ar}$ atmosphere. $\mathrm{CaO}$ was prepared by calcination of $\mathrm{CaCO}_{3}$ in air at $1273 \mathrm{~K}\left(1000{ }^{\circ} \mathrm{C}\right)$ for $12 \mathrm{~h}$. The compositions of the initial ladle-refining slags with different $\mathrm{CaF}_{2}$ contents and composition of $\mathrm{WM}$ are listed in Table I, and the initial compositions of

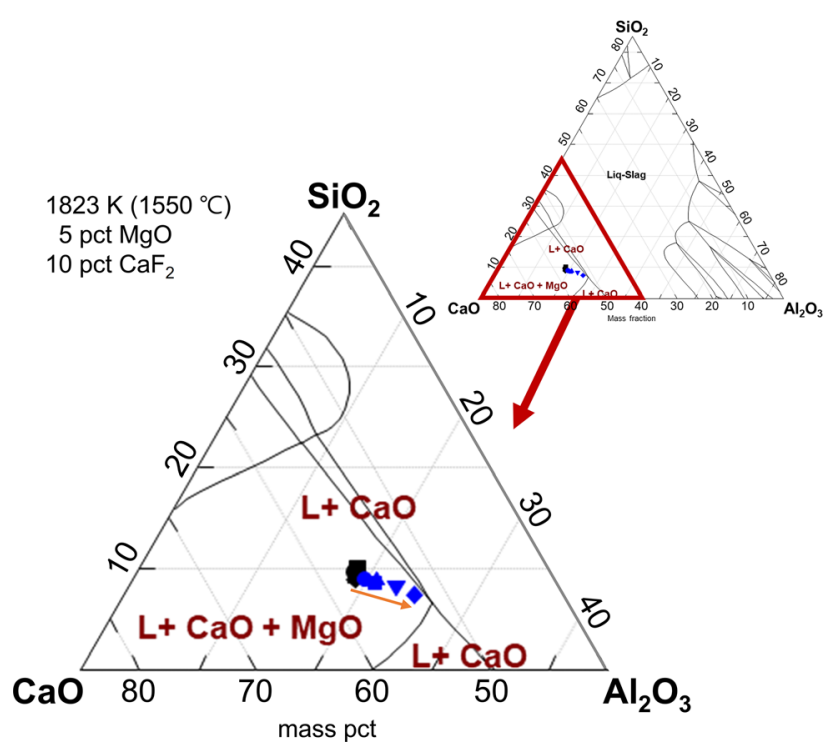

Fig. 2-Experimental composition of the mixed slag used in the current study, as represented in the $\mathrm{CaO}-\mathrm{Al}_{2} \mathrm{O}_{3}-\mathrm{SiO}_{2}-5 \mathrm{MgO}-10 \mathrm{CaF}_{2}$ (mass pct) phase diagram at $1823 \mathrm{~K}\left(1550{ }^{\circ} \mathrm{C}\right)$, calculated using FactSage $^{\mathrm{TM}} 7.3$ software.

WM-fluxed (mixed) slags are listed in Table II. The $\mathrm{CaO}-\mathrm{SiO}_{2}-\mathrm{Al}_{2} \mathrm{O}_{3}-5 \mathrm{MgO}-10 \mathrm{CaF}_{2}$ (mass pct) pseudoternary phase diagram calculated using FactSage $^{\mathrm{TM}}$ software (ver. 7.3) is shown in Figure 2.

Suction sampling and water quenching were conducted with a quartz tube ([ID]: $4 \mathrm{~mm}$ ) to obtain steel samples, and slag samples were obtained using a stainless steel rod combined with nuts. All samples were collected at varied times $(0,5,10,15,20,30$, and 60 minutes). After the experiments were finished, the sulfur content of the metal and slag samples were obtained using a combustion analyzer (ELTRA, CS-800). The compositions of the steel and slag samples were determined by means of X-ray fluorescence spectroscopy (XRF; ZSX Primus IV, Rigaku) and inductively coupled plasma atomic emission spectrometry (ICP-AES; 
Table III. Final Compositions of Mixed Slags (Mass Pet) and Sulfur Distribution Ratio at 60 Min

\begin{tabular}{|c|c|c|c|c|c|c|c|c|c|}
\hline Slag ID & $\mathrm{CaO}$ & $\mathrm{SiO}_{2}$ & $\mathrm{Al}_{2} \mathrm{O}_{3}$ & $\mathrm{MgO}$ & $\mathrm{CaF}_{2}$ & $\mathrm{Na}_{2} \mathrm{O}$ & {$[\% \mathrm{~S}]_{\text {metal }}$} & $(\% \mathrm{~S})_{\text {slag }}$ & $\mathrm{L}_{\mathrm{S}}$ \\
\hline $10 \mathrm{CaF}_{2} \mathrm{LS}$ & 56.7 & 11.2 & 17.6 & 5.2 & 9.3 & - & 0.0008 & 0.66 & $810( \pm 5)$ \\
\hline $7 \mathrm{CaF}_{2} \mathrm{LS}$ & 59.2 & 10.3 & 18.6 & 5.4 & 6.5 & - & 0.0009 & 0.57 & $610( \pm 6)$ \\
\hline $3 \mathrm{CaF}_{2} \mathrm{LS}$ & 60.3 & 10.6 & 21.0 & 5.2 & 2.9 & - & 0.0009 & 0.92 & $990( \pm 3)$ \\
\hline $0 \mathrm{CaF}_{2} \mathrm{LS}$ & 63.4 & 9.1 & 21.4 & 6.1 & - & - & 0.0015 & 0.95 & $650( \pm 5)$ \\
\hline $3 \mathrm{CaF}_{2} \mathrm{LS}+5 \mathrm{WM}$ & 61.1 & 9.7 & 21.6 & 4.7 & 2.8 & 0.1 & 0.0009 & 0.75 & $890( \pm 10)$ \\
\hline $3 \mathrm{CaF}_{2} \mathrm{LS}+10 \mathrm{WM}$ & 60.3 & 9.4 & 22.6 & 4.9 & 2.7 & 0.2 & 0.0011 & 0.80 & $760( \pm 9)$ \\
\hline $7 \mathrm{CaF}_{2} \mathrm{LS}+10 \mathrm{WM}$ & 57.6 & 9.3 & 21.7 & 4.8 & 6.3 & 0.2 & 0.0012 & 0.72 & $600( \pm 3)$ \\
\hline $7 \mathrm{CaF}_{2} \mathrm{LS}+20 \mathrm{WM}$ & 56.5 & 8.5 & 23.8 & 5.3 & 5.6 & 0.2 & 0.0012 & 0.70 & $610( \pm 7)$ \\
\hline $7 \mathrm{CaF}_{2} \mathrm{LS}+30 \mathrm{WM}$ & 55.4 & 7.9 & 26.0 & 5.8 & 4.9 & 0.3 & 0.0012 & 0.69 & $560( \pm 11)$ \\
\hline
\end{tabular}

Spectro Arcos,). The final compositions of the mixed slags and sulfur distribution ratio after $60 \mathrm{~min}$ experiments are listed in Table III.

\section{RESULTS AND DISCUSSION}

\section{A. Effect of White Mud on Melting Behavior of Ladle Slag}

The melting temperature and solid phase fraction of the WM-fluxed (mixed) slags at $1823 \mathrm{~K}\left(1550{ }^{\circ} \mathrm{C}\right)$ calculated from FactSage ${ }^{\mathrm{TM}} 7.3$ software are shown in Figure 3 vs. the amount of added WM. Both the melting temperature and solid phase fraction of the mixed slags tended to decrease with increasing WM content. These properties are important parameters affecting the desulfurization rate by accelerating the initial fluxing to form a liquid slag. The effect of the addition of WM on the melting behavior of mixed slag during heating cycle is shown in Figure 4. It was observed that $T_{\mathrm{h}}$ and $T_{\mathrm{f}}$ decreased with increasing WM content. Wang et al. ${ }^{[12]}$ explained that $T_{\mathrm{h}}$ and $T_{\mathrm{f}}$ symbolize the transition points of sluggish flow and liquid mobility, respectively. Therefore, the observed decreases in $T_{\mathrm{h}}$ and $T_{\mathrm{f}}$ with increasing WM content represent slag fluidity starting at lower temperatures.

The height of the slag sample during heating as a function of time (i.e., temperature) is shown in Figure 5(a). The sample height was constant until reaching the deformation temperature $\left(T_{\mathrm{d}}\right)$, above which it rapidly decreased (Section $A$ ). This tendency was also observed to accelerate with increasing WM content. The maximum slope of the lines in section $A\left(=-\mathrm{d} R_{\mathrm{H}} / \mathrm{d} t\right.$, melting rate $)$ vs. the WM content is shown in Figure 5(b). The melting rate increased with increasing WM content. Considering that the slag-metal reaction occurs at the slag-metal interface under the steady state condition without slag-metal emulsification due to vigorous stirring, the present results indicate that the reaction area of the mixed slag increases more rapidly in cases in which more WM has been added. Therefore, we consider the addition of WM to have a positive effect on the slag-metal reaction by ensuring fluidity of the slag at a lower temperature.

The snapshot images acquired 5 minutes after the WM-fluxed slag was added in the molten steel during desulfurization experiments are shown in Figure 6. When WM is added, a noticeable fume was emitted. Considering the final slag composition after the experiment (Table III) in

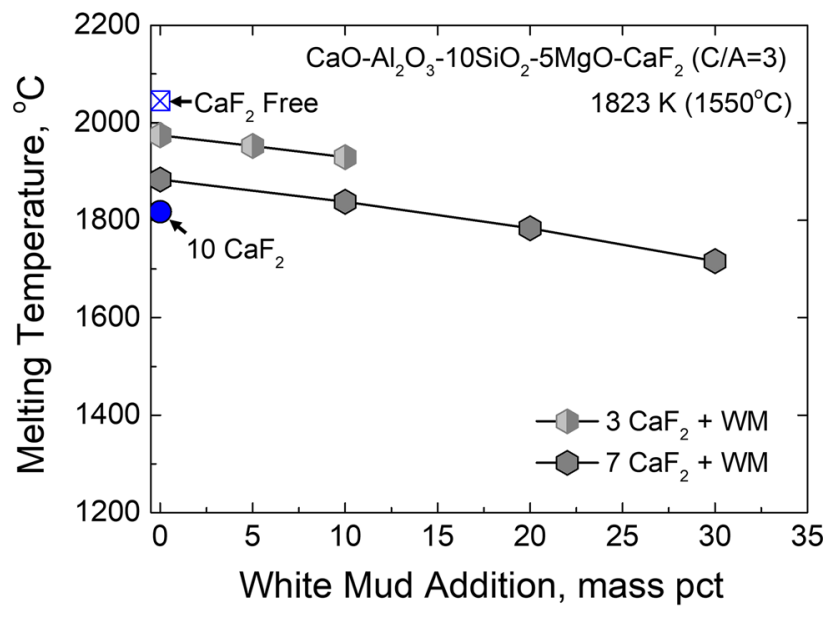

(a)

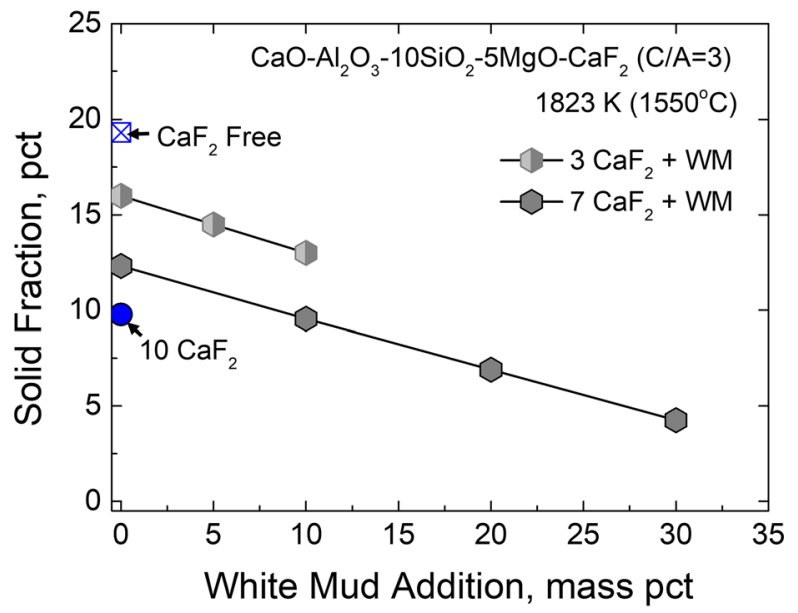

(b)

Fig. 3-(a) Melting temperature and (b) solid fraction of the mixed slags at $1823 \mathrm{~K}\left(1550{ }^{\circ} \mathrm{C}\right)$ vs. white mud content (Calculated from FactSage $^{\mathrm{TM}} 7.3$ software).

the present study and previous works conducted at high temperatures in the References 24, 25, 28 and 29 the fume generated during the experiment was expected to be a gas containing sodium. $\mathrm{Na}_{2} \mathrm{O}$ is well known as a material that volatilizes at high temperatures, and many studies have been conducted regarding changes in the physicochemical properties of slag due to the volatilization of $\mathrm{Na}_{2} \mathrm{O} \cdot{ }^{[24,25]}$ In the present study, the $\mathrm{Na}_{2} \mathrm{O}$ content of the mixed slag was relatively low (less than 3 mass pct, in Table II), and lower in 


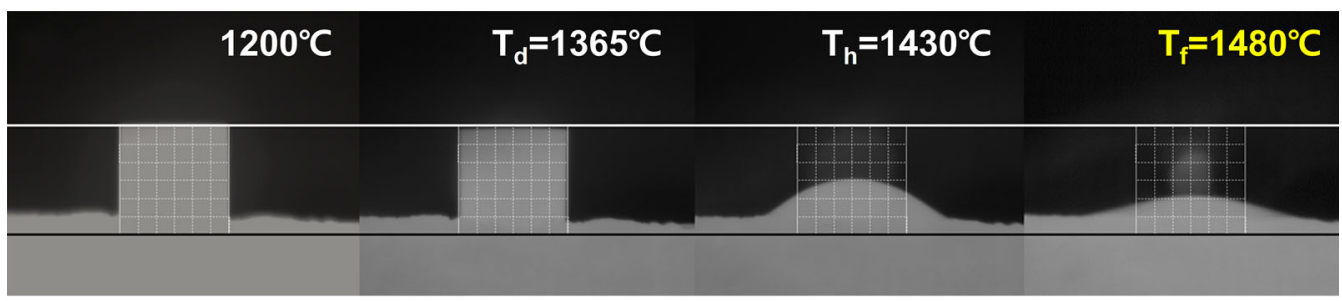

(a)

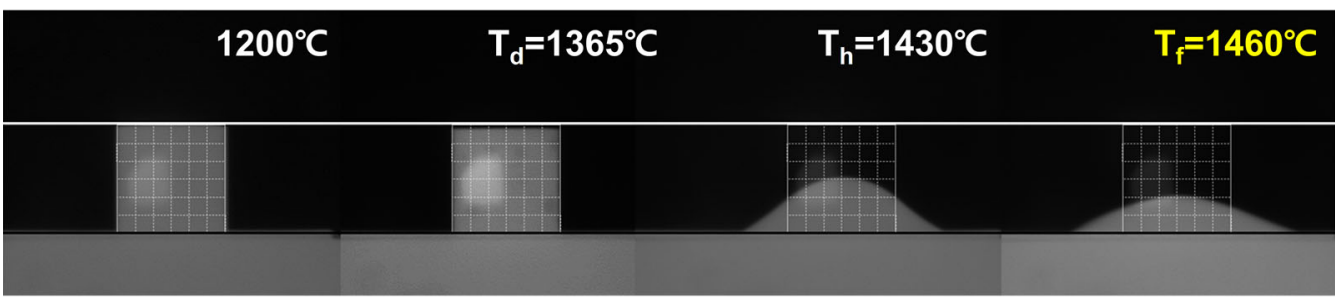

(b)

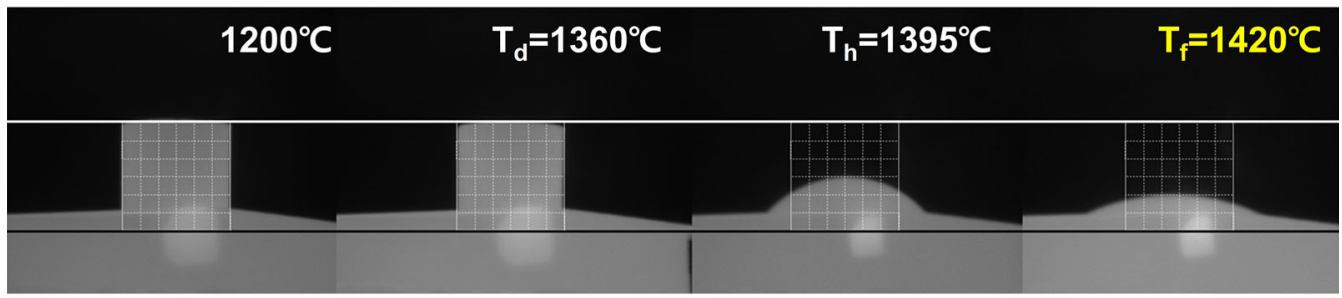

(c)

Fig. 4 -Images of samples at $T_{\mathrm{d}}$, $T_{\mathrm{h}}$, and $T_{\mathrm{f}}:(a) 3 \mathrm{CaF}_{2}$ ladle slag, (b) $3 \mathrm{CaF}_{2}$ ladle slag $+5 \mathrm{WM}$, and (c) $3 \mathrm{CaF}_{2}$ ladle slag $+10 \mathrm{WM}$.

the final slag (Table III). Also, mixed slags were multiphase, i.e., solid $\mathrm{CaO}$ (approx. 10 pct) was present in all conditions. This means that the activity of $\mathrm{CaO}$, a representative basic component that dominates the desulfurization reaction, was unity. Therefore, it is considered that the effect of $\mathrm{Na}_{2} \mathrm{O}$, which was easily volatilized during experiments, on the desulfurization efficiency is not significant, and the effect of $\mathrm{Na}_{2} \mathrm{O}$ on the refractory wear is also not able to be significant. A degradation behavior of refractory material due to the addition of WM will be investigated further in the future.

With added WM, it was observed that more liquid slag was produced compared to the case for conventional ladle slag containing $\mathrm{CaF}_{2}$ at the same time (5 min). These results are in good agreement with the findings discussed above that WM has a positive effect on the melting rate of mixed ladle slag (Figures 4 and 5). In conclusion, because the addition of WM has a positive effect on initial melting rate of the slag, it is advantageous for producing the liquid slag rapidly after the slag is added. Therefore, it can be predicted that increasing the amount of added WM will have a positive effect on the initial desulfurization rate of molten steel.

\section{B. Effect of White Mud on Desulfurization Kinetics of Molten Steel}

The desulfurization ratio, i.e., $[\text { mass pct } \mathrm{S}]_{t=t} /[\text { mass pct } \mathrm{S}]_{t=0}$, in the molten steel as a function of reaction time at different fluxing conditions is shown in Figure 7. In most cases, a large amount of sulfur was removed within 10 minutes, and the sulfur concentration remaining in the molten steel after the 30 -minute experiment was very low, approx. 11( \pm 3$)$ ppm. The initial sulfur removal rate of the $\mathrm{CaF}_{2}$-free slag was relatively lower than the others. The desulfurization index at $10 \mathrm{~min}$ after slag addition is shown in Figure 8, including for comparison data on ferromanganese slag (FMS) and red mud (RM) fluxing from our previous report. ${ }^{[26]}$ The initial desulfurization index is defined as

$$
\begin{aligned}
& \text { Desulfurization index }(\mathrm{pct}) \\
& =\frac{[\text { mass pct } \mathrm{S}]_{0}-[\text { mass pct } \mathrm{S}]_{t=10 \mathrm{~min}}}{[\text { mass pet } \mathrm{S}]_{0}} \times 100,
\end{aligned}
$$

where $[\text { mass pet } \mathrm{S}]_{0}$ is the initial sulfur concentration in the molten steel and [mass pct $\mathrm{S}]_{t}=10 \mathrm{~min}$ is sulfur concentration in the steel at time $t=10$ minutes. In most cases, more than 90 pct of the sulfur was removed from the molten steel within 10 minutes, and the corresponding desulfurization indexes were equivalent to that of the conventional ladle slag with $10 \mathrm{pct}$ $\mathrm{CaF}_{2}$. However, in the $\mathrm{CaF}_{2}$-free case and the FMS and RM excessive addition cases, the desulfurization index significantly decreased, while in the case of excessive addition of WM, the desulfurization index increased.

The desulfurization flux equation is given in Eqs. [2] through [4]. ${ }^{[26,30-32]}$ The overall mass transfer coefficient calculated based on flux equation is shown in Figure 9. 


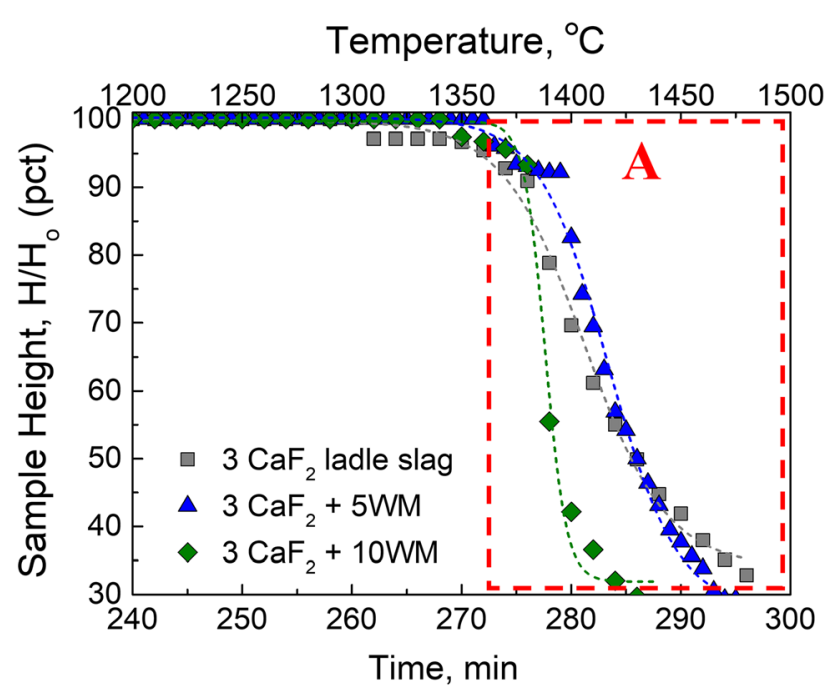

(a)

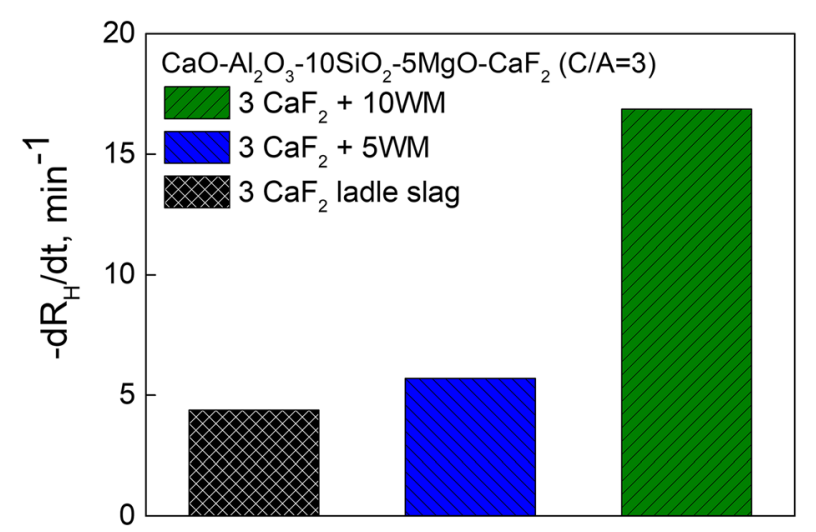

(b)

Fig. 5- (a) Sample height ratio $\left(H / H_{\mathrm{o}}\right)$ vs. time and temperature; $(b)$ melting rate of each slag sample in Section $A$.

$$
\begin{gathered}
J=k_{\mathrm{O}}\left(C_{\mathrm{m}}^{\mathrm{b}}-\frac{C_{\mathrm{s}}^{\mathrm{b}}}{L_{\mathrm{S}}}\right) \\
k_{\mathrm{O}}=\frac{1}{\frac{1}{k_{\mathrm{m}}}+\frac{\rho_{\mathrm{m}}}{\rho_{\mathrm{s}} k_{\mathrm{s}}}} \\
L_{\mathrm{S}}=\frac{(\text { mass pct } \mathrm{S})_{\text {slag }}}{[\text { mass pet } \mathrm{S}]_{\text {metal }}}
\end{gathered}
$$

where $J, C^{\mathrm{b}}, L_{\mathrm{S}}, \rho$, and $k_{\mathrm{O}}$, respectively, represent the molar flux of $\mathrm{S}\left(\mathrm{mol} \mathrm{m}{ }^{-2} \mathrm{~s}^{-1}\right)$, the molar concentration of $\mathrm{S}$ in the bulk phase $\left(\mathrm{mol} \mathrm{m}^{-3}\right)$, the $\mathrm{S}$ distribution ratio, the density $\left(\mathrm{kg} \mathrm{m}^{-3}\right)$, and the overall mass transfer coefficient $\left(\mathrm{m} \mathrm{s}^{-1}\right)$. Subscripts $\mathrm{m}$ and $\mathrm{s}$, respectively, refer to the metal and slag phase. Here, $k_{\mathrm{m}}$ and $k_{\mathrm{s}}$ were calculated by using Eqs. [5] and [6]. ${ }^{[26,30-32]}$

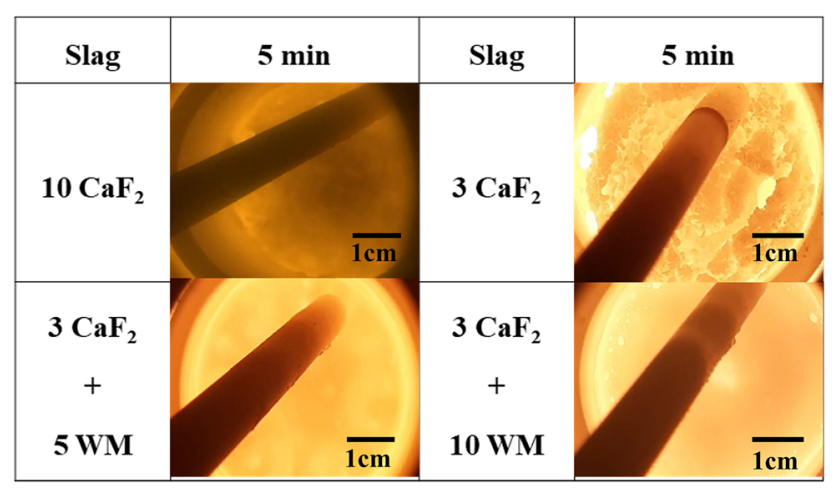

Fig. 6-Snapshot images of initial slag $\left(\begin{array}{llll}5 & \mathrm{~min}) & \text { during }\end{array}\right.$ desulfurization experiment at $1823 \mathrm{~K}\left(1550{ }^{\circ} \mathrm{C}\right)$.

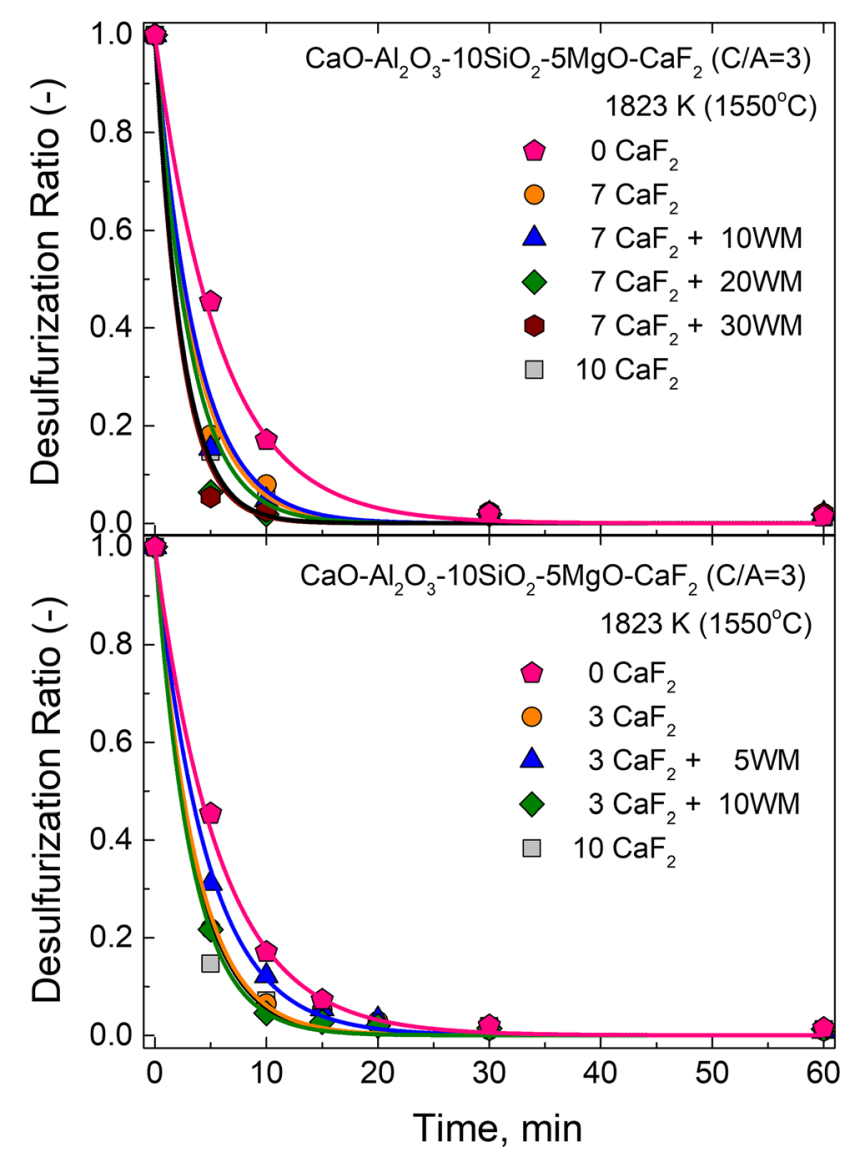

Fig. 7-Desulfurization ratio vs. reaction time for slags having various $\mathrm{CaF}_{2}$ and $\mathrm{WM}$ contents at $1823 \mathrm{~K}\left(1550^{\circ} \mathrm{C}\right)$.

$$
\begin{aligned}
& -\left(\frac{W_{\mathrm{m}}}{\rho_{\mathrm{m}} A}\right)\left(\frac{[\text { pct } S]_{0}-[\text { pct } \mathrm{S}]_{\mathrm{eq}}}{[\mathrm{pct} \mathrm{S}]_{0}}\right) \ln \left(\frac{[\mathrm{pct} \mathrm{S}]_{t}-[\mathrm{pct} \mathrm{S}]_{\mathrm{eq}}}{[\mathrm{pct} \mathrm{S}]_{0}-[\mathrm{pct} \mathrm{S}]_{\mathrm{eq}}}\right) \\
& =k_{\mathrm{m}} t
\end{aligned}
$$




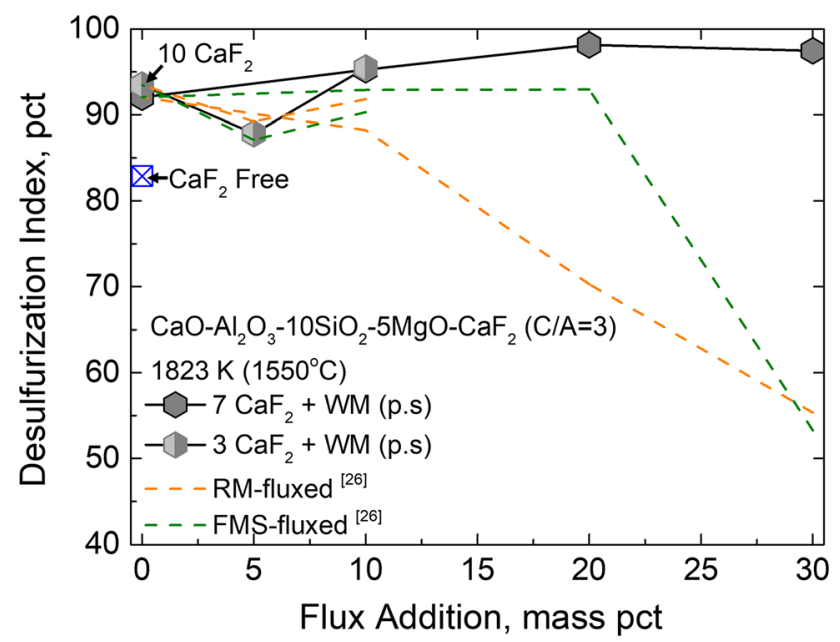

Fig. 8-Desulfurization index of mixed slags at $10 \mathrm{~min}$ (p.s. represents present study).

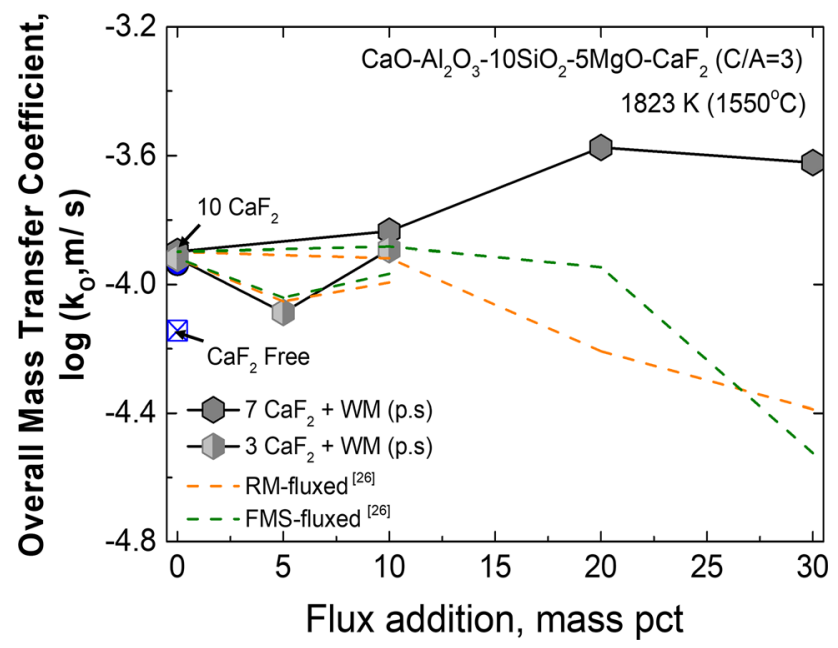

Fig. 9-Overall mass transfer coefficient of sulfur vs. WM fluxing addition at $1823 \mathrm{~K}\left(1550^{\circ} \mathrm{C}\right)$ (p.s. represents present study).

$$
-\left(\frac{W_{\mathrm{s}}}{\rho_{\mathrm{s}} A}\right)\left(\frac{[\text { pct S }]_{\mathrm{eq}}}{[\text { pct S }]_{0}}\right) \ln \left(\frac{[\text { pct S }]_{t}-[\text { pct } \mathrm{S}]_{\mathrm{eq}}}{[\text { pct S }]_{0}-[\text { pct } S]_{\mathrm{eq}}}\right)=k_{\mathrm{s}} t
$$

where $W, A$, [pct $\mathrm{S}$ ], and $t$, respectively, represent the weight $(\mathrm{kg})$, reaction area $\left(\mathrm{m}^{2}\right), \mathrm{S}$ concentration (mass pct), and reaction time (seconds). Subscripts 0 and eq represent initial $(t=0)$ and equilibrium $\left(t=t_{\text {eq }}\right)$ conditions. In the present study, sulfur in molten steel was rapidly removed within the $20 \mathrm{~min}$, and the same level of sulfur was observed from 30 to 60 minutes. Therefore, the equilibrium concentration of sulfur, $[\text { pct } S]_{\text {eq }}$ in molten steel was taken as an average value of the sulfur concentration measured at 30 and 60 minutes.
The equilibrium S concentration in metal and slag, and the $\mathrm{S}$ distribution ratio are listed in Table III. Additionally, data on FMS and RM fluxing from the previous report were added for comparison. ${ }^{[26]}$ In a similar trend to that observed for the desulfurization index (Figure 8), the overall mass transfer coefficient, $k_{\mathrm{O}}$, of WM-fluxed slag was almost equivalent to or higher than that of the conventional ladle slag containing 10 pet $\mathrm{CaF}_{2}$. However, in the $\mathrm{CaF}_{2}$-free case and the FMS and RM excessive addition cases, $k_{\mathrm{O}}$ decreased.

From Eq. [3], $k_{\mathrm{O}}$ depends on $k_{\mathrm{m}}$ and $k_{\mathrm{s}} L_{\mathrm{S}} \cdot k_{\mathrm{m}}$ is defined as $D_{\mathrm{m}} / \delta\left(D_{\mathrm{m}}\right.$ is diffusion coefficient of sulfur in molten steel, and $\delta$ is diffusional boundary layer thickness) and is affected by kinetic factors such as the viscosity of steel melt. ${ }^{[31]}$ Therefore, in the present study, because the steel conditions (such as composition, inductive stirring, temperature, etc.) were fixed, $k_{\mathrm{m}}$ was constant. Hence, constant $k_{\mathrm{O}}$ means that $k_{\mathrm{m}}$ is more dominant than $k_{\mathrm{S}} L_{\mathrm{S}}$ in Eq. [3], and the mass transfer of sulfur in metal phase is closer to the desulfurization rate controlling step. However, a decrease in $k_{\mathrm{O}}$ (in the $\mathrm{CaF}_{2}$-free, and FMS and RM excessive addition conditions) means that the desulfurization rate is controlled by slag phase mass transfer and/or metal-slag mixed transportation process, which are dominantly dependent on the thermophysical properties of the slag such as viscosity. ${ }^{[26]}$

Because the only independent variable in the current study is the composition of mixed slag, as affected by the addition of $\mathrm{CaF}_{2}$ and/or industrial wastes (FMS, RM, WM), the effect of slag composition upon the physicochemical properties of the slag should be considered. Herein we consider the kinetic and the thermodynamic factors of slag to understand the effects of the physicochemical properties of slag upon the desulfurization mechanism. ${ }^{[26]}$ To quantitatively express the thermodynamic properties of liquid slag, the sulfide capacity $\left(C_{\mathrm{S}^{2-}}\right)$ of the liquid slag (not the bulk slag) was calculated using FactSage ${ }^{\mathrm{TM}} 7.3$ software and is shown in Figure 10, which includes for comparison data on FMS and RM fluxing from the present authors' previous study. ${ }^{[26]}$ Even though the porous solid $\mathrm{CaO}$ can absorb sulfur from molten steel via the so-called 'Capillary refining' mechanism, ${ }^{[33-36]}$ it is generally known that the solid $\mathrm{CaO}$ did not participate in the desulfurization reaction in view of slag chemistry theory. ${ }^{[37]}$ Hence, in present study, it was assumed that solid $\mathrm{CaO}$ [approx. 10 pet from Figure 3(b)] does not participate in the desulfurization reaction. ${ }^{[37]}$ The sulfide capacity has been used as a characteristic property to quantitatively represent the sulfur absorption ability of a slag as a function of composition from a thermodynamic point of view since Fincham and Richardson originally defined it as given in Eq. [8]. ${ }^{[38-42]}$ This was obtained from the desulfurization reaction (Eq. [7]) based on gas-slag equilibrium. 


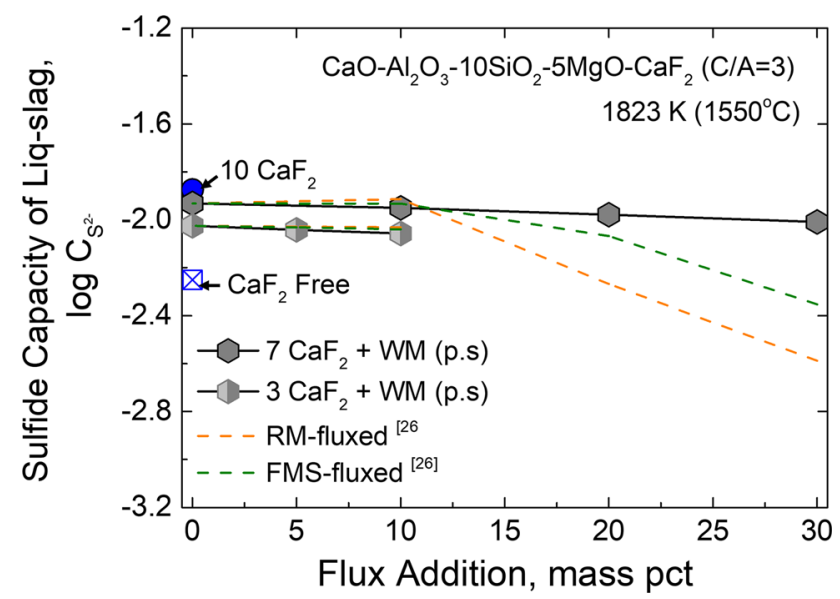

Fig. 10 - Sulfide capacity of the liquid slag $v s$. WM fluxing addition at $1823 \mathrm{~K}\left(1550^{\circ} \mathrm{C}\right)$ (p.s. represents present study).

$$
\begin{gathered}
\frac{1}{2} \mathrm{~S}_{2}(\mathrm{~g})+\left(\mathrm{O}^{2-}\right)=\left(\mathrm{S}^{2-}\right)+\frac{1}{2} \mathrm{O}_{2}(\mathrm{~g}) \\
\left.C_{\mathrm{S}^{2-}}=\frac{K_{[7]} \cdot a_{\mathrm{O}^{2-}}}{f_{\mathrm{S}^{2-}}}=\text { (mass pct } \mathrm{S}^{2-}\right) \cdot\left(\frac{p_{\mathrm{O}_{2}}}{p_{\mathrm{S}_{2}}}\right)^{\frac{1}{2}} .
\end{gathered}
$$

where $K_{[7]}$ is the equilibrium constant of Eq. [7], $a_{\mathrm{O}^{2-}}$ is the activity of $\mathrm{O}^{2-}$ ions in the slag (i.e., the basicity of the slag), $f_{\mathrm{S}^{2-}}$ is the activity coefficient of sulfide ions in the slag, and $p_{i}$ is the partial pressure of the gaseous species $i$. Thus, the sulfide capacity is a characteristic function of basicity and sulfide ion stability in the slag at a given temperature. In current study, the oxygen partial pressure $\left(p_{\mathrm{O}_{2}}=10^{-14} \mathrm{~atm}\right)$ and sulfur partial pressure $\left(p_{\mathrm{S}_{2}}=10^{-10} \mathrm{~atm}\right)$ were fixed by converting the average sulfur and oxygen contents in the steel sample, and the composition of the liquid slag was taken as the input parameter in the calculation using FactSage $^{\mathrm{TM}} 7.3$ software. Compared to the use of 10 pct $\mathrm{CaF}_{2}$, the sulfide capacity of the liquid slag was modeled to decrease with the addition of FMS and $\mathrm{RM}$, but remain equivalent with the addition of WM in Figure 10.

In the previous work, ${ }^{[26]}$ it was concluded that when FMS and RM were added, the composition of the mixed slag changed with the reaction time $\left(\mathrm{SiO}_{2}\right.$ increased) due to the chemical reactions $([\mathrm{Si}]+(\mathrm{MnO})=2[\mathrm{Mn}]+$ $\left.\left(\mathrm{SiO}_{2}\right),[\mathrm{Si}]+2\left(\mathrm{Fe}_{t} \mathrm{O}\right)=2 t \mathrm{Fe}(1)+\left(\mathrm{SiO}_{2}\right)\right)$ between metal and slag, and thus the sulfide capacity decreased. However, when WM was added in the present work, because it does not contain reducible oxides such as $\mathrm{Fe}_{\mathrm{t}} \mathrm{O}$ and $\mathrm{MnO}$, the composition of the slag did not vary depending on the reaction time. As shown in Table II, with the addition of $\mathrm{WM}$, the content of $\mathrm{CaO}$ and $\mathrm{SiO}_{2}$ in the mixed slag decreased (but not significant) and the content of $\mathrm{Al}_{2} \mathrm{O}_{3}$ increased. However, as mentioned above, the mixed slag used in this study was a multiphase slag, and solid $\mathrm{CaO}$ (approx. 10 pet) was present in all conditions. This means that the activity of $\mathrm{CaO}$, a basic oxide that dominates the desulfurization

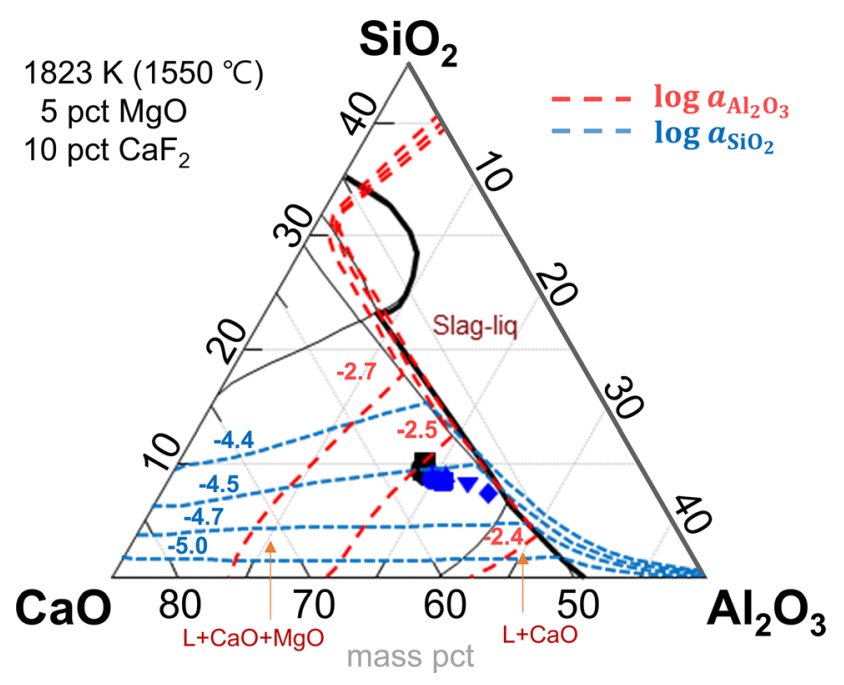

Fig. 11-Iso-activity contours of $\mathrm{Al}_{2} \mathrm{O}_{3}$ and $\mathrm{SiO}_{2}$ in the $\mathrm{CaO}$-corner of the $\mathrm{CaO}-\mathrm{SiO}_{2}-\mathrm{Al}_{2} \mathrm{O}_{3}-5 \mathrm{MgO}-10 \mathrm{CaF}_{2}$ slag at $1823 \mathrm{~K}\left(1550{ }^{\circ} \mathrm{C}\right)$.

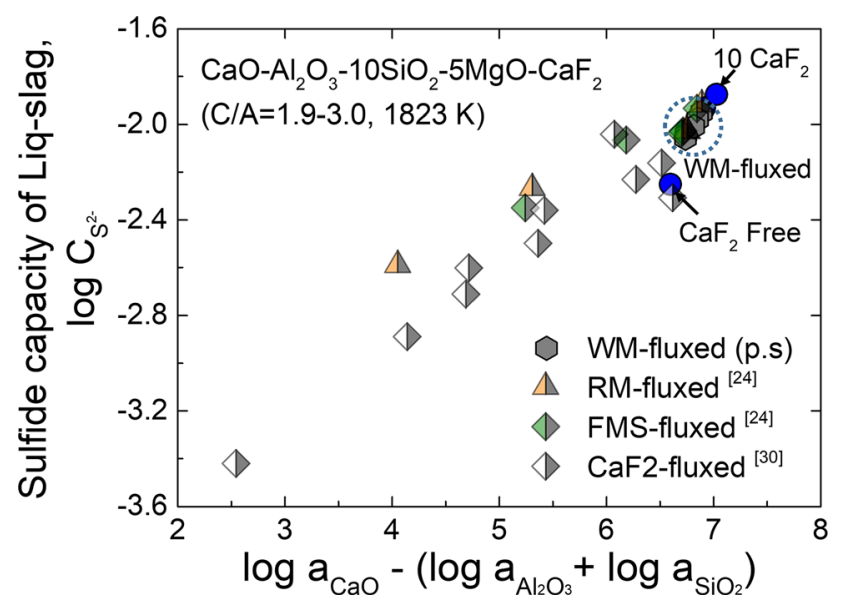

Fig. 12-Sulfide capacity of the liquid slag vs. $\log a_{\mathrm{CaO}}-$ $\left(\log a_{\mathrm{Al}_{2} \mathrm{O}_{3}}+\log a_{\mathrm{SiO}_{2}}\right)$ at $1823 \mathrm{~K}\left(1550{ }^{\circ} \mathrm{C}\right)$ (p.s. represents present study).

reaction, was unity and thus it can be assumed that the effect of $\mathrm{CaO}$ on the desulfurization reaction is equivalent under all experimental conditions. Therefore, the observed change of the sulfide capacity was caused by the changes in the contents of $\mathrm{Al}_{2} \mathrm{O}_{3}$ and $\mathrm{SiO}_{2}$.

It is known that as the content of $\mathrm{Al}_{2} \mathrm{O}_{3}$ and $\mathrm{SiO}_{2}$ in slag increases, the sulfide capacity decreases. ${ }^{[3,26,38-42]}$ The iso-activity lines of $\mathrm{Al}_{2} \mathrm{O}_{3}$ and $\mathrm{SiO}_{2}$ at $1823 \mathrm{~K}(1550$ ${ }^{\circ} \mathrm{C}$ ) are shown in Figure 11 . The activity of $\mathrm{Al}_{2} \mathrm{O}_{3}$ increased, while that of $\mathrm{SiO}_{2}$ decreased, respectively, with increasing WM content. Therefore, despite the increase in the amount of alumina according to the amount of WM added, the almost equivalent sulfide capacity observed was attributed to a counterbalancing effects of increased $\mathrm{Al}_{2} \mathrm{O}_{3}$ activity and decreased $\mathrm{SiO}_{2}$ activity.

The effects of the activities of $\mathrm{CaO}, \mathrm{SiO}_{2}$, and $\mathrm{Al}_{2} \mathrm{O}_{3}$ upon the sulfide capacity of liquid slag are shown in Figure 12; for comparison, the sulfide capacity and activity values of slags of similar composition carried 
Table IV. Viscosity of Slags (dPa s) at $1823 \mathrm{~K}\left(1550^{\circ} \mathrm{C}\right)$

\begin{tabular}{|c|c|c|c|c|c|}
\hline & & $\begin{array}{l}\text { Viscosity of Liquid } \\
\text { Slag, } \eta_{\mathrm{o}}\end{array}$ & $\begin{array}{l}\text { Mass Fraction of Solid } \\
\text { Monoxide }\end{array}$ & $\begin{array}{c}\text { Volume Fraction of } \\
\text { Monoxide }\end{array}$ & $\begin{array}{c}\text { Apparent } \\
\text { Viscosity } \\
\eta\end{array}$ \\
\hline \multirow{4}{*}{$\begin{array}{l}\text { Ladle Slag } \\
\quad \text { (LS) }\end{array}$} & $10 \mathrm{CaF}_{2} \mathrm{LS}$ & 0.60 & 0.096 & 0.079 & 0.80 \\
\hline & $7 \mathrm{CaF}_{2} \mathrm{LS}$ & 0.65 & 0.126 & 0.100 & 0.94 \\
\hline & $3 \mathrm{CaF}_{2} \mathrm{LS}$ & 0.73 & 0.157 & 0.131 & 1.20 \\
\hline & $0 \mathrm{CaF}_{2} \mathrm{LS}$ & 0.80 & 0.198 & 0.159 & 1.47 \\
\hline WM-Fluxed & $3 \mathrm{CaF}_{2} \mathrm{LS}+5 \mathrm{WM}$ & 0.76 & 0.154 & 0.124 & 1.17 \\
\hline \multirow[t]{4}{*}{ Slag } & $3 \mathrm{CaF}_{2} \mathrm{LS}+10 \mathrm{WM}$ & 0.78 & 0.142 & 0.117 & 1.15 \\
\hline & $7 \mathrm{CaF}_{2} \mathrm{LS}+10 \mathrm{WM}$ & 0.70 & 0.111 & 0.088 & 0.92 \\
\hline & $7 \mathrm{CaF}_{2} \mathrm{LS}+20 \mathrm{WM}$ & 0.75 & 0.100 & 0.079 & 0.90 \\
\hline & $7 \mathrm{CaF}_{2} \mathrm{LS}+30 \mathrm{WM}$ & 0.81 & 0.090 & 0.071 & 0.90 \\
\hline
\end{tabular}

out at the same condition, i.e., $1823 \mathrm{~K}\left(1550{ }^{\circ} \mathrm{C}\right)$ were added. ${ }^{[26,32]}$ The sulfide capacity of the slags increases with increasing the activity ratio, $\log a_{\mathrm{CaO}}-\left(\log a_{\mathrm{Al}_{2} \mathrm{O}_{3}}+\log a_{\mathrm{SiO}_{2}}\right)$. In the previous study, ${ }^{[26]}$ a decrease of sulfide capacity was observed due to a change of the slag composition (namely, due to an increase in $\mathrm{SiO}_{2}$ content) under conditions of an excess fluxing of RM or FMS. However, in the case of WM fluxing, the slag had a $\log a_{\mathrm{CaO}}-$ $\left(\log a_{\mathrm{Al}_{2} \mathrm{O}_{3}}+\log a_{\mathrm{SiO}_{2}}\right)$ index ranging from 6.5 to 7.0 , almost equivalent to that of the conventional (10 pct) $\mathrm{CaF}_{2}$-fluxed ladle slag, and representing sufficient sulfide capacity for the intended purpose.

The viscosity of the liquid slag was calculated using FactSage $^{\mathrm{TM}} 7.3$ software to account for the kinetic factor affecting the desulfurization rate and is shown in Table IV. The viscosity of the liquid slag slightly increased with the amount of WM added because WM contains about 41 mass pet $\mathrm{Al}_{2} \mathrm{O}_{3}$ (Table I), which is significantly higher than $\mathrm{Al}_{2} \mathrm{O}_{3}$ content of ladle slag (about 20 mass pct). ${ }^{[3,10,43-45]}$ However, as mentioned earlier, the mixed slag used in the present study is a highly basic multiphase slag (i.e., $\mathrm{L}+\mathrm{CaO}$; 10 to 15 pet $\mathrm{CaO})$; accordingly, the apparent viscosity was calculated using the Einstein-Roscoe equation (Eq. [9]), which reflects the effect of solid phase $(\mathrm{CaO})$ fractions. ${ }^{[26,45-50]}$

$$
\eta=\frac{\eta_{0}}{(1-a f)^{\mathrm{n}}}
$$

where $\eta$ is the apparent viscosity of multiphase slag (dPa s, poise), $\eta_{0}$ is the viscosity of liquid ( $\mathrm{dPa} \mathrm{s}$, poise), and $f$ is the volume fraction of solid, and $a$ and $n$ are constant. Here, the volume fraction of solid was calculated from the following method: (i) calculate the equilibrium mass fraction of each phase of the mixed slag at the experimental temperature using FactSage software; (ii) the density of liquid slag, solid $\mathrm{CaO}$, and $\mathrm{MgO}$ was assumed to be $2.65 \mathrm{~g} / \mathrm{cm}^{3}, 3.34 \mathrm{~g} / \mathrm{cm}^{3}$, and $3.58 \mathrm{~g} / \mathrm{cm}^{3}$, respectively. ${ }^{[31,51]}$; (iii) calculate the volume fraction of solid monoxide ( $\mathrm{Ca}, \mathrm{Mg}) \mathrm{O}$ phase (mainly $\mathrm{CaO}$ ). In Eq. [9], it was assumed that the solid particles were uniformly dispersed with a spherical shape, from which $a=1.35$ and $n=2.5$ could be taken. ${ }^{26,45-50]}$ The apparent viscosity values calculated based on Eq. [9] are listed in Table IV. In the previous study, ${ }^{[26]}$ it was concluded that the $\mathrm{CaF}_{2}$-free condition negatively affected the initial desulfurization reaction due to the high viscosity caused by the existence of solid $\mathrm{CaO}$ in the slag.

Contrastingly, with the addition of WM, the solids fraction decreases, which is shown in Figure 3(b). Although the viscosity of the liquid slag slightly increases due to an increase in $\mathrm{Al}_{2} \mathrm{O}_{3}$ content, the apparent viscosity of the slag is equivalent to that of the conventional $\mathrm{CaF}_{2}$-containing ladle slag due to a decrease in the solid fraction by WM fluxing.

In summary, the addition of WM is considered to increase the initial desulfurization rate by promoting slag melting and thus providing a favorable environment for the initial slag-metal reaction. In addition, unlike FMS and $\mathrm{RM}$ additives, WM does not change the composition of ladle slag because it does not cause a chemical reaction with the elements (i.e., Al and/or Si) of the molten steel, so there is no change in sulfide capacity and viscosity over time. Consequently, WM addition can provide desulfurization rate equivalent to or higher than that of conventional 10 pet $\mathrm{CaF}_{2}$-containing ladle slag, and hence WM appears suitable to partially replace fluorspar in secondary refining processes.

\section{CONCLUSIONS}

In this study, the effects of the industrial waste white mud (WM) upon the desulfurization kinetics of molten steel were studied at $1823 \mathrm{~K}\left(1550{ }^{\circ} \mathrm{C}\right)$. The addition of WM had a positive effect on desulfurization rate by lowering the melting temperature and the solid phase fraction of the slag at the experimental temperature. An increase in the WM content increased the initial desulfurization rate by decreasing $T_{\mathrm{h}}$ ( $=$ hemisphere temperature) and $T_{\mathrm{f}}$ (= flow temperature) allowing the slag to melt rapidly and form a large amount of liquid slag during the initial period of the reaction. Unlike other industrial wastes such as ferromanganese slag and red mud investigated earlier, WM did not change the slag composition through chemical reactions with components in the steel (i.e., maintaining an inert slag). When WM was added, because the sulfide capacity and viscosity were equivalent to that of $\mathrm{CaF}_{2}$-containing multiphase slag due to less amounts of solid $(\mathrm{CaO})$ fraction, the overall mass transfer coefficient of sulfur 
$\left(k_{O}\right)$ was equivalent to or higher than that of (10 pct) $\mathrm{CaF}_{2}$-containing multiphase ladle-refining slag.

\section{ACKNOWLEDGMENTS}

This research was partly supported by the Korea Institute for Advancement of Technology (KIAT, with Grant No. P0002019), funded by the Ministry of Trade, Industry \& Energy (MOTIE), Korea. Also, this research was partly supported by Korea Evaluation Institute of Industrial Technology (KEIT, with Grant No. 20009956), funded by the MOTIE, Korea

\section{FUNDING}

Open access funding provided by Royal Institute of Technology.

\section{CONFLICT OF INTEREST}

On behalf of all authors, the corresponding author states that there is no conflict of interest.

\section{OPEN ACCESS}

This article is licensed under a Creative Commons Attribution 4.0 International License, which permits use, sharing, adaptation, distribution and reproduction in any medium or format, as long as you give appropriate credit to the original author(s) and the source, provide a link to the Creative Commons licence, and indicate if changes were made. The images or other third party material in this article are included in the article's Creative Commons licence, unless indicated otherwise in a credit line to the material. If material is not included in the article's Creative Commons licence and your intended use is not permitted by statutory regulation or exceeds the permitted use, you will need to obtain permission directly from the copyright holder. To view a copy of this licence, visit http://creativecommons.org/licenses/by/4.0/.

\section{REFERENCES}

1. E. Andersson and D. Sichen: Steel Res. Int., 2009, vol. 80, pp. 544 51 .

2. A. Putan, V. Putan, T. Heput, and A. Socalici: Rev. Metall., 2013, vol. 49 , pp. $31-44$.

3. K.C. Mills: Slag Atlas, 2nd ed., Verlag Stahleisen $\mathrm{GmbH}$, Düsseldorf, 1995, pp. 198-377.

4. J.H. Park and D.J. Min: J. Non-Cryst. Solids, 2004, vol. 337, pp. $150-56$.

5. J.H. Park, D.J. Min, and H.S. Song: ISIJ Int., 2002, vol. 42, pp. $38-43$.

6. F. Shahbazian, D. Sichen, K.C. Mills, and S. Seetharaman: Ironmak. Steelmak., 1999, vol. 26, pp. 193-99.

7. P. Kozakevitch: Rev. Metall., 1954, vol. 51, pp. 569-87.

8. J.R. Maclean, P.W. Kingston, J.B. MacDonald, and W.F. Caley: Ironmak. Steelmak., 1997, vol. 24, pp. 406-11.

9. J.H. Park, D.J. Min, and H.S. Song: Metall. Mater. Trans. B, 2002, vol. 33B, pp. 723-28.

10. T.S. Kim and J.H. Park: ISIJ Int., 2014, vol. 54, pp. 2031-38.

11. M.O. Suk and J.H. Park: J. Am. Ceram. Soc., 2009, vol. 92, pp. 717-23.

12. H. Wang, L. Yang, G. Li, X. Zhu, H. Zhu, and Y. Zhao: J. Iron Steel Res. Int., 2013, vol. 20, pp. 21-24.

13. J.S. Han, J.G. Kang, J.H. Shin, Y. Chung, and J.H. Park: Ceram. Int., 2018, vol. 44, pp. 13197-13204.
14. J.H. Park, M.O. Suk, I.H. Jung, M. Guo, and B. Blanpain: Steel Res. Int., 2010, vol. 81, pp. 860-68.

15. A.I. Zaitsev, A.V. Leites, A.D. Litvina, and B.M. Mogutnov: Steel Res., 1994, vol. 65, pp. 368-74.

16. Y. Kashiwaya and A. Cramb: Metall. Mater. Trans. B, 2001, vol. 32B, pp. 401-07.

17. J.H. Park and D.J. Min: Steel Res. Int., 2004, vol. 75, pp. 807-11.

18. A.S.B. Moreira, C.A. Silva, and I.A. Silva: REM: Int. Eng. J., 2018, vol. 71, pp. 261-67.

19. H. Mizukmi, M. Ishikawa, T. Hirata, T. Kamiyama, and K. Ichikawa: ISIJ Int., 2004, vol. 44, pp. 623-29.

20. J. Zhou, X. Bi, Z. Huang, Z. Wen, F. Yang, and Y. Jin: $A d v$. Mater. Res., 2012, vol. 402, pp. 227-35.

21. Fluorspar supply: trade trends \& new sources: http://imformed.com/f luorspar-supply-trade-trends-new-sources/. Āccessed 1 Feb 2021.

22. T.S. Tribe, P.W. Kingston, J.B. MacDonald, and W.F. Caley: Ironmak. Steelmak., 1994, vol. 21, pp. 145-49.

23. S. H. Amini, O. Ostrovski, and M. P. Brungs: Proc. of 7th Int. Conf. on Molten Slags, Fluxes and Salts, The South African Institute of Mining and Metallurgy, 2004, pp. 595-99.

24. J.Y. Choi, D.J. Kim, and H.G. Lee: ISIJ Int., 2001, vol. 3, pp. 216-24.

25. Z. Tong, J. Qiao, and X. Jiang: ISIJ Int., 2017, vol. 57, pp. 245-53.

26. TS. Jeong and J.H. Park: Metall. Mater. Trans. B, 2020, vol. 51B, pp. 2309-20.

27. A. Mclean, Y. Yang, and M. Barati: Min. Process. Extr. Metall., 2017, vol. 126, pp. 106-15.

28. R.H. Lamoreaux and D.L. Hildenbrand: J. Phys. Chem. Ref. Data, 1984, vol. 13, pp. 151-73.

29. M. Li, T. Utigard, and M. Barati: Metall. Mater. Trans. B, 2015, vol. 46B, pp. 74-82.

30. B. Deo and R. Boom: Fundamentals of Steelmaking Metallurgy, Prentice Fall, New York, 1993.

31. J.K. Jung and J.J. Pak: J. Kor. Inst. Met. Mater., 2000, vol. 38, pp. 585-90.

32. J.K. Kang, J.H. Shin, Y. Chung, and J.H. Park: Metall. Mater. Trans. B, 2017, vol. 48B, pp. 2123-35.

33. T. Tanaka, Y. Ogiso, M. Ueda, and J. Lee: ISIJ Int., 2010, vol. 50, pp. 1071-77.

34. Y. Kishimoto, S. Utada, T. Iguchi, Y. Mori, M. Osawa, T. Yokokawa, T. Kobayashi, K. Kawagishi, S. Suzuki, and H. Harada: Metall. Mater. Trans. B, 2020, vol. 51B, pp. 293-305.

35. N. Kikuchi: ISIJ Int., 2020, vol. 60, pp. 2731-44.

36. Y. Kishimoto, T. Kono, T. Horie, T. Yokokawa, M. Osawa, K. Kawagishi, S. Suzuki, and H. Harada: Metall. Mater. Trans. B, 2021, vol. 52B, pp. 1450-62.

37. K. Takahashi, K. Utagawa, H. Shibata, S. Kitamura, N. Kikuchi, and Y. Kishimoto: ISIJ Int., 2012, vol. 52, pp. 10-17.

38. CJB. Fincham and F.D. Richardson: Proc. R. Soc. Lond. A, 1954, vol. 223 , pp. $40-62$.

39. M. Hino, S. Kitagawa, and S. Ban-ya: ISIJ Int., 1993, vol. 33, pp. $36-42$.

40. Y.B. Kang and A.D. Pelton: Metall. Mater. Trans. B, 2009, vol. 40B, pp. 979-94.

41. G.H. Park, Y.B. Kang, and J.H. Park: ISIJ Int., 2011, vol. 51, pp. $1375-82$.

42. J.H. Park and G.H. Park: ISIJ Int., 2012, vol. 52, pp. 764-69.

43. P. Kozakevitch: Rev. Met. Paris, 1960, vol. 57, pp. 149-60.

44. J.S. Machin and T.E. Yee: J. Am. Ceram. Soc., 1948, vol. 37, pp. $177-86$.

45. E.T. Turkdogan: Physicochemical Properties of Molten Slags and Glasses, Metals Society, London, 1983, pp. 11-20.

46. A. Einstein: Ann. Phys, 1906, vol. 19, pp. 289-306.

47. R. Roscoe: Br. J. Appl. Phys, 1952, vol. 3, pp. 267-69.

48. S.H. Seok, S.M. Jung, Y.S. Lee, and D.J. Min: ISIJ Int., 2007, vol. 47, pp. 1090-96.

49. R.O. Pezzin, A.P.L. Berger, F.F. Grillo, E. Junca, H.S. Furtado, and J.R. Oliveira: J. Mater. Res. Technol., 2020, vol. 9, pp. 836-46.

50. H.Y. Wang, G.H. Zhang, and K.C. Chou: Metall. Mater. Trans. $B, 2020$, vol. 51B, pp. 2057-67.

51. W.M. Hynes: CRC Handbook of Chemistry and Physics, 92th ed., CRC Press, Taylor and Francis, Boca Raton, 2011.

Publisher's Note Springer Nature remains neutral with regard to jurisdictional claims in published maps and institutional affiliations. 